\title{
New oral anticoagulants: how safe are they?
}

\author{
C Chapman $^{1 *}$, R de S Kulasiri ${ }^{2}$ \\ Consultant Anaesthetist ${ }^{1}$, QEQM Hospital, Margate, Kent, UK, Consultant Anaesthetist ${ }^{2}$, National \\ Hospital of Sri Lanka, Colombo, Sri Lanka.
}

\section{"Corresponding author:champachapman@ rocketmail.com}

\begin{abstract}
Introduction of the new oral anticoagulants (NoACs) to prevent and treat thromboembolic phenomena is one of the most significant innovations in clinical practice in the past 50 years. It has been about 6 years since the first new oral anticoagulant gained approval for stroke prevention in atrial fibrillation (AF) in the United States. The new anti-coagulants (Factor Xa inhibitors and factor IIa inhibitors) have major pharmacologic advantages over vitamin $\mathrm{K}$ antagonists (inhibiting clotting factors II, VII, IX, and X) and a very few disadvantages. Warfarin is still the drug of choice for patients with mechanical heart valves. If the patients' compliance is debatable NoACs will not be the drugs of choice as the off-set toxicity is high to create new clots. Cost of the NoACs is higher than warfarin but somewhat similar to low molecular weight heparin (which is administered subcutaneously). With increasing familiarity among the practitioners NoACs will establish a bigger market, and long term effects of using these drugs will be known.

In this article we have compared warfarin with the commonly used new oral anticoagulants to determine whether their use is safe in Sri Lanka.
\end{abstract}

Keywords: Stroke; bleeding; atrial fibrillation; pulmonary embolism; prevention

\section{Introduction}

$\mathrm{AF}$ is the most common sustained cardiac arrhythmia and is associated with an increased risk of stroke and other thromboembolic events. ${ }^{1}$ Deep vein thrombosis (DVT) and pulmonary embolism (PE) are serious but preventable conditions. Prophylactic treatment is cheaper than treating them.

There are new drugs that have been introduced to the market in the recent past that have made a difference to the patient's life styles when compared with the existing treatment regimes.

The high risk patients who are on these drugs can present for surgical interventions which pose a challenge for the clinicians to time the procedures and offer them an uneventful outcome.

\section{Warfarin Sodium}

The most widely prescribed oral anti-coagulant is wafarin sodium. ${ }^{2}$. It is a synthetic vitamin $\mathrm{K}$ antagonist. It was discovered accidently by observing the cows dying of haemorraghic shock after ingestion of straw spoiled by sweet clover $^{3,5}$ when they underwent minor surgical procedures. In 1948 the research carried out at the University of Wisconsin discovered warfarin and hence it gained the name WARF (Wisconsin Alumni Research Foundation) and "arin" because it is derived from coumarin (natural substance found in many plants). ${ }^{4,5}$

Mechanism of action

Warfarin acts by inhibiting the synthesis of vitamin $\mathrm{K}$ dependent clotting factors 11, VII, $1 \mathrm{X}$ and $\mathrm{X}$ and the anticoagulant proteins $\mathrm{C}$ and $\mathrm{S} .{ }^{4}$

It is best known to anticoagulate in stagnant blood flow. Stagnant blood flow would occur in patients with DVT, patients with replaced heart valves with blood pooling behind the valves and those having dysfunctional cardiac atria giving 
rise to thrombo-embolic events. Wafarin is also used in anti-phospholipid syndrome. ${ }^{5}$

Warfarin is not effective after myocardial infarction. Anti-platelet drugs are more effective in preventing new thrombus formation in coronary arteries ${ }^{4}$

\section{Dosing of warfarin}

Warfarin therapy has many limitations. Dosing of the drug is difficult due to most of the commonly used medications (macrolide and many other broad spectrum antibiotics, anti fungals and corticosteroids) and food items(beef liver, leafy green vegetables, cabbage, ginger, starflower oil, fish oil, cranberries and soya beans)interacting with warfarin and as a result the anticoagulant effect can be varied ${ }^{5,6}$. Therefore close monitoring of the international normalised ratio (INR) is required until a stable targeted INR (usually 2-3 and in patients with mechanical heart valves a higher value of 3-4) is achieved. ${ }^{7}$ The patients should be educated well about the drug and food interactions. And if any unknown food items or drugs were ingested INR monitoring should be carried out.

During the first 3 days of warfarinization the levels of anticoagulation factors (protein $\mathrm{C}$ and protein $\mathrm{S}$ ) drop faster than procoagulation proteins - factors $11, \mathrm{VII}, 1 \mathrm{X}$ and $\mathrm{X}$. There is a temporary hypercoagulable state in this initial period which needs bridging with another anticoagulant (usually heparin). ${ }^{7,8}$

\section{$\underline{\text { Contraindications }}$}

Warfarin is contra indicated in pregnancy. When administered in the first trimester at 6-9 weeks of gestation foetus acquires skeletal abnormalities (nasal hypoplasia, narrowed nasal bridge, scoliosis, calcifications in the vertebral column, femur or heel bone and bradydactyly). In the third trimester if administered the foetus can get central nervous system disorders (spasticity, seizures) and eye defects. ${ }^{5}$

Any patient with malignant hypertension or has suffered sequel due to hypertension like haemorrhagic stroke should not receive wafarin at any cost. ${ }^{6}$

\section{Adverse Effects}

Commonest side effect is bleeding. Risk of severe bleeding is not high unless the INR is above 4-5. ${ }^{7,9}$ When patients are on anti-platelet or anti-inflammatory drugs or have a high alcohol consumption the risk of bleeding is high. Bleeding can occur anywhere and most catastrophic is into the brain and spinal cord. ${ }^{9}$

Rare but a serious complication associated with warfarin therapy is necrosis. This is seen in patients with protein $\mathrm{C}$ (innate anticoagulant) deficiency. Skin necrosis and gangrene of limbs are being reported. Heparin is added when starting warfarin therapy to combat this ${ }^{5}$

In the recent past there have been various new oral anticoagulants introduced to the market. They have become popular due to the rapid onset and off set of action, few drug interactions, predictable pharmacokinetics and eliminating the requirement for regular coagulation monitoring. ${ }^{10}$

The most commonly used drugs are Rivaroxaban, Dabigatran and Apixaban.

\section{Rivaroxaban}

This was the first available oral factor $\mathrm{Xa}$ inhibitor that came to the market. It is well absorbed by the gut and the maximum effect is seen in 4 hours after administration and the effect lasts for 8-12 hours. Since the factor Xa activity doesn't return to normal by 24 hours once daily dosing is adequate. ${ }^{11}$

Rivaroxaban is licensed for use to prevent deep vein thrombosis in patients undergoing elective hip and knee surgery in the post-operative period and in the prevention of embolic events in patients with non-valvular atrial fibrillation(AF) with one or more risk factors such as congestive cardiac failure, age(more than 75years),diabetes mellitus and transient ischaemic events. ${ }^{12}$ 
Rivaroxaban is an oxizolidinone derivative that is highly selective in inhibiting the action of Factor Xa. It has a high bioavailability and has a rapid onset of action with no effects on the platelets or on factor II (thrombin). ${ }^{11}$

Being a potent anticoagulant rivaroxaban is associated with bleeding. A possible antidote is still under research (and exanat alpha- antidote for factor Xa inhibitors) in phase 3 trials and is yet to be approved by US Food and Drug administration $^{12}$. Major or life threatening bleeding will require antidote therapy.

Patients with reduced kidney function should be given lower doses. If the Creatinine clearance $(\mathrm{CrCl})$ is less than $30 \mathrm{ml} / \mathrm{min}$ rivaroxaban shouldn't be prescribed.

Dosing of Rivaroxaban

Any dose above $10 \mathrm{mg}$ is given with food.

\section{DVT prophylaxis in orthopaedic surgery. ${ }^{13}$}

Initial dose 6 hours after surgery after haemostasis is established. After knee replacement $10 \mathrm{mg}$ a day should be given for 12 days. After hip replacement - 10mg a day for 35 days.

Prophylactic therapy for non valvulr AF- 20 mg

\section{Treatment of DVT and Pulmonary embolism} (PE)

$15 \mathrm{mg}$ a day for 21 days, then $20 \mathrm{mg}$ a day for 6 months.

\section{Dose modifications ${ }^{12}$}

If the $\mathrm{CrCl}$ is $15-50 \mathrm{ml} / \mathrm{min}$ in Non valvular AF$15 \mathrm{mg}$ a day

If $\mathrm{Crcl}<15 \mathrm{ml} / \mathrm{min}$ avoid rivaroxaban

\section{For post-operative thrombo prophylaxis}

If $\mathrm{CrCl}$ is $30-50 \mathrm{ml} / \mathrm{min}$ no dose adjustments but use with caution. If $\mathrm{Crcl}<30 \mathrm{ml} / \mathrm{min}$ avoid rivaroxaban for post-operative thrombo prophylaxis.

Any liver failure or coagulopathy should be contraindications for rivaroxaban therapy and it should be avoided in pregnancy and lactation.

\section{Dabigatran}

This is a direct thrombin inhibitor that is used to reduce the risk for stroke and systemic embolism in patients with non valvular $\mathrm{AF}$ and to prevent and treat venous thromboembolism. ${ }^{14}$

A laboratory test to assess anti coagulation is not available for dabigatran.

Most commonly reported side effect of dabigatran is gastro intestinal symptoms. When compared to warfarin patients treated with dabigatran has fewer life threatening bleeds or other major bleeds but gastro intestinal bleeding tends to be higher than with warfarin. ${ }^{14}$

Dabigatran produces an optimal effect within 23 hours of ingestion and has a half-life of 12-14 hours. Fatty foods can delay the absorption but bioavailability is unaffected. If combined with a proton pump inhibitor the absorption is moderately decreased and therefore is not recommended. Dabigatran capsule has tartaric acid which lowers the $\mathrm{pH}$ of the stomach and is required for absorption, but can give rise to effects like dyspepsia.

Renal impairment requires dose adjustments with dabigatran. ${ }^{14}$

\section{Dosing of dabigatran}

Creatinine clearance of over $50 \mathrm{mls} / \mathrm{min}-150$ $\mathrm{mg}$ twice daily can be given.

If creatinine clearance is $30-50 \mathrm{mls} / \mathrm{min}-75 \mathrm{mg}$ twice daily

If the clearance is less than $15 \mathrm{mls} / \mathrm{min}$ - should be avoided.

Dabigatran is the only novel anti-coagulant that has a Food and Drug Administration (USA) approved reversal agent. Idarucizumab can be used when reversal of the anticoagulant effects are needed for emergency surgery or urgent procedures, or in the event of life-threatening or uncontrolled bleeding. ${ }^{15}$

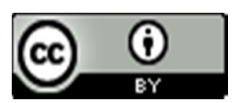

(C) 2016.Chapman et al. This is an Open Access article distributed under the terms of the Creative Commons Attribution License(http://creativecommons.org/licenses/by/4. 0), which permits unrestricted use, distribution, and reproduction in any medium, provided the original work is properly credited 


\section{Apixaban}

Apixaban is a highly selective, orally bioavailable, and reversible direct inhibitor of free and clot-bound factor Xa. Factor Xa catalyzes the conversion of prothrombin to thrombin, the final enzyme in the coagulation cascade that is responsible for fibrin clot formation. Apixaban has no effect on platelet aggregation.

Apixaban and other novel oral anticoagulants appear equally effective in prevention of nonhaemorrhagic stroke in people with $\mathrm{AF}$ and have a lower risk of intra cranial bleeding. ${ }^{16}$

Apixaban is also effective is prevention of DVT in post hip and knee surgery, treatment of DVT and PE and reducing the risk of recurring DVT and PE after initial therapy. ${ }^{16}$

When different products were available in the market there is a choice for the clinicians. There were 3 major randomised trials carried out, ROCKET-AF (rivaroxaban versus warfarin), RE-LY (dabigatran versus warfarin) and ARISTOTLE (apixaban versus warfarin). ${ }^{17}$

The trials helped to compare the risks, benefits, long term effects and the cost to evaluate the long term effectiveness of these drugs compared to warfarin on patients with non valvular AF.

Dabigatran showed a significant reduction in thrombotic stroke. Apixaban showed a reduction in major bleeding and mortality. Also gastro intestinal bleeding was much less compared to other drugs. They also showed that Factor X inhibitors are less dependent on renal elimination and have fewer gastro intestinal effects. There was more compliance with rivaroxaban as it is given once daily. New oral anticoagulants dosing have to be adjusted in renal insufficiency but warfarin can be given in renal impairment. All the oral anti-coagulants are not safe in pregnancy.
Premature discontinuation of the new oral anticoagulants increases the risk of thrombosis for reasons other than pathological bleeding or completion of therapy course. It is not due to any rebound effect from discontinuation, but due to having no protection against the causative factor for embolic process. To reduce this risk, administering another anticoagulant is advised.

Comparison of the new oral anticoagulants with warfarin $^{18}$

\begin{tabular}{|c|c|c|c|}
\hline & Rivaroxaban & Apixaban & Dabigatran \\
\hline $\begin{array}{l}\text { Non valvular atrial } \\
\text { fibrillation }\end{array}$ & $\begin{array}{l}\text { Non inferior to } \\
\text { warfarin }\end{array}$ & $\begin{array}{l}20 \% \\
\text { reduction } \\
\text { ARISOTLE }\end{array}$ & $\begin{array}{l}34 \% \text { reduction } \\
\text { RE-LY }\end{array}$ \\
\hline $\begin{array}{l}\text { Heart valve } \\
\text { replacement }\end{array}$ & No studies & No studies & No studies \\
\hline $\begin{array}{l}\text { Rheumatic } \\
\text { valvular disease }\end{array}$ & No studies & No studies & No studies \\
\hline $\begin{array}{l}\text { Gastro intestinal } \\
\text { bleeding }\end{array}$ & Can be increased & Minor & Can be increased \\
\hline $\begin{array}{l}\text { Intra cranial } \\
\text { haemorrhage }\end{array}$ & $\begin{array}{l}40 \% \text { reduced } \\
\text { than warfarin }\end{array}$ & $\begin{array}{l}50 \% \text { reduced } \\
\text { than warfarin }\end{array}$ & $\begin{array}{l}74 \% \text { reduced } \\
\text { than warfarin }\end{array}$ \\
\hline Major Bleeding & similar & $30 \%$ reduction & similar \\
\hline Drug Dose & Once daily & Twice daily & Twice daily \\
\hline $\begin{array}{l}\text { Renal } \\
\text { Excretion }\end{array}$ & $\begin{array}{l}\text { Less dependent. } \\
\text { Dose } \\
\text { modifications } \\
\text { required }\end{array}$ & $\begin{array}{l}\text { Less dependent. } \\
\text { Dose } \\
\text { modifications } \\
\text { required }\end{array}$ & $\begin{array}{l}\text { Mainly renal } \\
\text { elimination. } \\
\text { Reduce dose } \\
\text { according to } \mathrm{Cr} \\
\text { clearance }\end{array}$ \\
\hline Risk of embolism & $\begin{array}{l}\text { High with missing } \\
\text { a dose }\end{array}$ & $\begin{array}{l}\text { High with missing } \\
\text { a dose }\end{array}$ & $\begin{array}{l}\text { High with missing } \\
\text { a dose }\end{array}$ \\
\hline $\begin{array}{l}\text { Drug and food } \\
\text { interactions }\end{array}$ & Minimal & Minimal & Minimal \\
\hline
\end{tabular}

New oral anticoagulants and neuraxial blocks

There are no contra indications for neuraxial blocks for patients on aspirin or non-steroidal anti-inflammatory drugs without other risk factors like hepatic insufficiency or excess alcohol consumption.

When spinal/epidural anaesthesia or puncture is utilized, patients who are being treated with antithrombotic agents for the prevention of thromboembolic complications are at risk for developing a haematoma, which can cause longterm or permanent paralysis. The risk of this may be increased by using epidural or 
intrathecal catheters after a surgical operation or from the concurrent use of medicinal agents that affect haemostasis.

Timing of the drug administration, special investigations and monitoring of the bleeding risk will enable us to find a safe time to initiate the regional technique.

We have summarised the data in the table below $^{19,20}$

\begin{tabular}{|c|c|c|c|c|c|}
\hline Drug & $\begin{array}{l}\text { Pre- } \\
\text { neuraxial } \\
\text { blockage } \\
\text { test }\end{array}$ & Timing of procedure & $\begin{array}{l}\text { Bridging } \\
\text { Therapy }\end{array}$ & \begin{tabular}{|l|} 
After \\
catheter \\
removal \\
when to \\
restart
\end{tabular} & Monitoring \\
\hline $\begin{array}{l}\text { Low } \\
\text { Molecular } \\
\text { Weight } \\
\text { Heparin } \\
\text { (LMWH) }\end{array}$ & $\begin{array}{l}\text { Most } \\
\text { specific is } \\
\text { Factor X, } \\
\text { but not } \\
\text { routinely } \\
\text { performed }\end{array}$ & $\begin{array}{l}12 \text { hours after } \\
\text { prophylactic }(0.5 \mathrm{mg} / \mathrm{kg}) \\
24 \mathrm{hrs} \text { after } \\
\text { therapeutic }(1 \mathrm{mg} / \mathrm{kg}) \\
\text { dose }\end{array}$ & Not & 4 hours & $\begin{array}{l}\text { No } \\
\text { additional } \\
\text { monitoring }\end{array}$ \\
\hline Warfarin & INR & $\begin{array}{l}5 \text { days or INR }<1.5 \\
\text { before procedure. }\end{array}$ & $\begin{array}{l}\text { Yes with } \\
\text { LMWH } \\
\text { for about } \\
2 \text { days till } \\
\text { INR> } \\
1.5\end{array}$ & $\begin{array}{l}\text { When } \\
\text { INR }<1.4\end{array}$ & $\begin{array}{l}\text { Daily INR } \\
\text { until dose } \\
\text { stable }\end{array}$ \\
\hline Rivaroxaban & No-test & $\begin{array}{l}24 \text { hour( } 2 x \text { half-life }) \text { for } \\
\text { regional blocks }\end{array}$ & $\begin{array}{l}\text { Not } \\
\text { required }\end{array}$ & \begin{tabular}{|l} 
after 6 \\
hours \\
$(24 \mathrm{hrs}$ if \\
traumatic \\
inj)
\end{tabular} & $\begin{array}{l}\text { None } \\
\text { available }\end{array}$ \\
\hline Apixaban & No-test & $\begin{array}{l}\text { Ideally } 48 \text { hours, but } \\
24 \mathrm{hrs} \text { in emergency }\end{array}$ & $\begin{array}{l}\text { Not } \\
\text { required }\end{array}$ & \begin{tabular}{|l} 
after 6 \\
hours \\
$(24 \mathrm{hrs}$ if \\
traumatic \\
inj)
\end{tabular} & $\begin{array}{l}\text { None } \\
\text { available }\end{array}$ \\
\hline Dabigatran & No test & $\begin{array}{l}1-2 \text { days }(\mathrm{CrCl}>50 \mathrm{ml} / \mathrm{min}) \\
4-5 \text { days }(\mathrm{CrCl}<30 \mathrm{ml} / \mathrm{min}) \\
\text { before regional blocks } \\
\text { and surgical procedures }\end{array}$ & $\begin{array}{l}\text { Not } \\
\text { required }\end{array}$ & \begin{tabular}{|l|} 
Restart \\
after 6 \\
hours \\
(24hrs if \\
traumatic \\
inj)
\end{tabular} & $\begin{array}{l}\text { None } \\
\text { available }\end{array}$ \\
\hline Clopidogrel & No test & $\begin{array}{l}7 \text { days following } \\
\text { cessation }\end{array}$ & $\begin{array}{l}\text { Not } \\
\text { required }\end{array}$ & 2 hours & $\begin{array}{l}\mathrm{P} 2 \mathrm{Y} 12 \\
\text { assay not } \\
\text { routinely } \\
\text { done }\end{array}$ \\
\hline $\begin{array}{l}\text { Unfractionate } \\
\text { d iv Heparin }\end{array}$ & APTT & $\begin{array}{l}\text { Administration of Heparin } \\
\text { should be } 1 \text { hour after the } \\
\text { block }\end{array}$ & \begin{tabular}{|l} 
Not \\
required
\end{tabular} & \begin{tabular}{|l|}
1 hour \\
before \\
subseque \\
nt dose \\
or 2-4 \\
hours \\
after last \\
dose of \\
Heparin \\
\end{tabular} & APTT \\
\hline $\begin{array}{l}\text { Subcutaneou } \\
\text { s heparin }\end{array}$ & APTT & $\begin{array}{l}\text { Performed before subcut } \\
\text { Heparin is } \\
\text { administered }(5000 \mathrm{u} / 12 \mathrm{hrl} \\
\text { y) }\end{array}$ & $\begin{array}{l}\text { Not } \\
\text { required }\end{array}$ & $\begin{array}{l}\text { Follow } \\
\text { same as } \\
\text { for iv } \\
\text { heparin }\end{array}$ & APTT \\
\hline
\end{tabular}

No anticoagulation should be carried out while an epidural catheter is in place other than sc heparin $<5000$ units $^{19}$
New oral anticoagulants have proved to be superior in treating non valvular AF compared to warfarin in many aspects. But the cost of the drugs is the only limiting factor compared to warfarin. Regular point of care testing requires the patients to attend outpatient clinics in developing countries. Educating the patients about the numerous food and drug interactions with warfarin also can be challenging which imposes close monitoring of INR. If the cost can balance the ease of use with the new oral anticoagulants they will have a role in thrombo prophylaxis for non valvular AF, following hip and knee replacement and treating and preventing DVT and PE.

\section{References}

1. Munger TM, Wu LQ, Shen WK. "Atrial fibrillation.". Journal of biomedical research. 2014;28(1): 17 .

http://dx.doi.org/10.7555/JBR.28.20130191

PMid:24474959 PMCid:PMC3904170

2. Holford NH. 'Clinical Pharmacokinetics and Pharmacodynamics of Warfarin Understanding the Dose-Effect Relationship"', Clinical Pharamacokinetics (Springer International Publishing) 1986;11(6): pp. 483-504. http://dx.doi.org/10.2165/00003088-19861106000005

PMid:3542339

3. Schofield FW. "Damaged sweet clover; the cause of a new disease in cattle simulating haemorrhagic septicemia and blackleg". J Am Vet Med Assoc 1924;64:553-6.

4. Hirsh J, Fuster V, Ansell J, Halperin JL. American heart association/ American college of cardiology foundation guide to warfarin therapy. J Am Coll Cardiol 2003; 41(9) http://dx.doi.org/10.1161/01.cir.0000063575.179 $04.4 \mathrm{e}$

5. Macina OT, Schardein JL. (2007). "Warfarin". Human Developmental Toxicants. Boca Raton: CRC Taylor \& Francis. pp. 193-4. ISBN 08493-7229-1.Retrieved on 15 December 2008 through Google Book Search

6. Holbrook AM, Pereira JA, Labirisi SR et al. Systemic overview of warfarin and its drug and food interactions. Arch Inter Med May 2005;165(10):1095-1106. 
http://dx.doi.org/10.1001/archinte.165.10.1095 PMid:15911722

7. Baglin TP, Keeling DM, Watson HG. (2005) Guidelines on oral anticoagulation (warfarin), third edn.,2005 British Society for Haematology, 132, 277-285.

8. Ansell J, Hirsh J, Hylek E et al. Pharmacology and management of Vitamin $\mathrm{K}$ antagonists. American College of chest physicians, evidence based clinical practice guideline (8th edition) 2008;133(6suppl):

9. Garcia et al. Practical management of coagulopathy associated with warfarin. BMJ 2010;340:c1813.

10. Bauer, K. A. "Pros and cons of new oral anticoagulants". Hematology 2013 (1): 464-470. http://dx.doi.org/10.1182/asheducation-

2013.1.464

PMid:24319220

11. Perzborn E, Roehrig SA; Kubitza D. Misselwitz F. "The discovery and development of rivaroxaban, an oral, direct factor Xa inhibitor". Nature Reviews Drug Discovery 2010;10 (1): 61-75.

http://dx.doi.org/10.1038/nrd3185

PMid:21164526

12. (2015) rivaroxaban $(\mathrm{Rx})$ Xarelto, Available at: http://www.medscape.com/ 999670 (Accessed: Drugs \& Neutraceuticals).

13. Eriksson BI, Borris LC, Dahl OE, Haas S et al. A Once-Daily, Oral, Direct Factor Xa Inhibitor, Rivaroxaban (BAY 59-7939), for Thromboprophylaxis after Total Hip Replacement. Circulation. 2006 Nov 28;114(22):2374-81

http://dx.doi.org/10.1161/CIRCULATIONAHA. 106.642074

PMid: 17116766

14. (2015) dabigatran, Available at: http://www.medscape.com/ (Accessed: Drugs \& Neutraceuticals).

15. Pollack CV, Reilly PA, Eikelboom $\mathrm{J}$ et al. Idarucizumab for Dabigatran Reversal. N Engl J Med2015;373:511-520.

http://dx.doi.org/10.1056/NEJMoa1502000 PMid:26095746

16. (2014) apixaban (Rx) Eliquis, Available at: Medscape (Accessed: news@ medscape.net).

17. Rao MP, Pokorney SD, Granger CB. Atrial Fibrillation: A Review of Recent Studies with a Focus on Those from the Duke Clinical Research
Institute Scientifica (Cairo) 2014; Article ID 901586, 11 pages

18. Hughes S. (January 18, 2013) Apixaban Approved: Now Which Anticoagulant to Use?, Available at: Medscape (Accessed: news@medscape.net).

19. Benzon HT. (2015) Regional Anesthesia in the Anticoagulated Patient, Available at: The New York school of regional anaesthesia

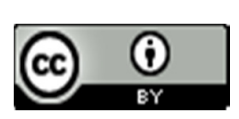

(C) 2016.Chapman et al. This is an Open Access article distributed under the terms of the Creative Commons Attribution License(http://creativecommons.org/licenses/by/4. 0), which permits unrestricted use, distribution, and reproduction in any medium, provided the original work is properly credited 